\title{
The Use of GIS and Google Earth for Preliminary Site Selection of Groundwater Recharge in the Azraq Oasis Area-Jordan
}

\author{
Rida Al-Adamat \\ Department of Surveying Engineering, Faculty of Engineering, Al Al-Bayt University, Mafraq, Jordan \\ Email: ridaali@aabu.edu.jo
}

Received March 14, 2012; revised April 13, 2012; accepted May 12, 2012

\begin{abstract}
Groundwater is considered to be the major water resource for many areas and the only source of water in some areas in Jordan. Some of Jordan groundwater resources are presently exploited at maximum capacity and in some cases are exploited beyond there safe yield. One of the efficient ways to fight the deficit in groundwater resources is through recharging the water tables naturally or artificially. This research aimed to select the optimum sites for groundwater recharge in the Azraq Oasis area/Jordan through the use of GIS techniques. The selection criteria were based on slope, drainage density, lineament density within the study area. The adopted selection technique was the Boolean techniques (Multiplication) within a Raster GIS. Thirty five sites were selected within the study area with areas vary between 5.2 ha to 273.5 ha. The total area that has the potential for groundwater recharge is 1659.5 ha which represents $c a$. $3.55 \%$ of the study area.
\end{abstract}

Keywords: GIS; Groundwater; Recharge; Jordan; Azraq Oasis

\section{Introduction}

In Jordan, groundwater is a major water resource for many areas of the country. However, Some of Jordan groundwater resources are presently exploited at maximum capacity and in some cases are exploited beyond their safe yield [1]. One of the efficient ways to overcome the deficit in groundwater resources is through recharging the water tables naturally or artificially [2]. In order to select the optimum sites for groundwater recharge, new techniques must be used. One of these techniques is GIS which plays a key role in maintaining data and analyzing optimal locations. It reduces time and cost of the site selection and provides a digital data bank for future monitoring program of the selected sites.

The use of GIS for selecting the optimum sites of groundwater recharge projects have been addressed in the literature by many researchers (e.g. [3-8]). In these researches, GIS was used in selecting the optimum sites for groundwater recharge projects at various parts of the world. In their quest to find the optimum sites, researchers applied GIS techniques on various maps including geology, fractures, soil, slope, rainfall and drainage.

There are two major techniques used within GIS environment to select the optimum site for any project; the Weighted Linear Combination (WLC) and the Boolean technique.
The Weighted Linear Combination (WLC) [9-16] is based on:

1) Standardizing the suitability maps,

2) Assigning weights of relative importance to the suitability's maps,

3) Assigning weights of relative importance to the suitability's maps,

4) Obtaining an overall suitability score.

While, in the Boolean technique [4,16-20], the variables are either true or false. This technique provides site selection of a project based on using either the OR (UN$I O N$ ) or the AND (INTERSECTION) operations.

This paper aims to use GIS and Google Earth to select the potential sites for groundwater recharge in the Azraq Oasis area/Jordan.

\section{Materials and Methods}

\subsection{Study Area}

The study area is located in the central northern part of Jordan. It lies with the Azraq Basin (Figure 1), with an estimated area of more than 46,756 ha. Azraq basin is considered one of the most important water sources in Jordan. Most of the pumped water is from the shallow aquifer system, which is currently overexploited. The basin has developed rapidly in the last ten years where 
significant parts of grazing lands are now used for agriculture. At the end of 1992 and as a direct result of the over pumping from the basin to agricultural activities and to supply Amman and Zarqa cities the natural springs in the basin dried out. This had lead to dry the oasis which considered as an alarming environmental disaster.

\subsection{Site Selection Criteria and Applied Technique}

The following table (Table 1) summarizes the preliminary site selection criteria for groundwater recharge within the study area.

In this research, the Boolean techniques will be used in selecting the optimum sites for groundwater recharge within the study area, Jordan. The implementation of this technique could be done through the use of raster calculation (multiplication) in ArcGIS (Raster GIS layers) or the use of Intersection (AND) command in ArcGIS (Vector GIS layers). In this research, raster calculation will be used on the available GIS data in order to perform the required data analysis.

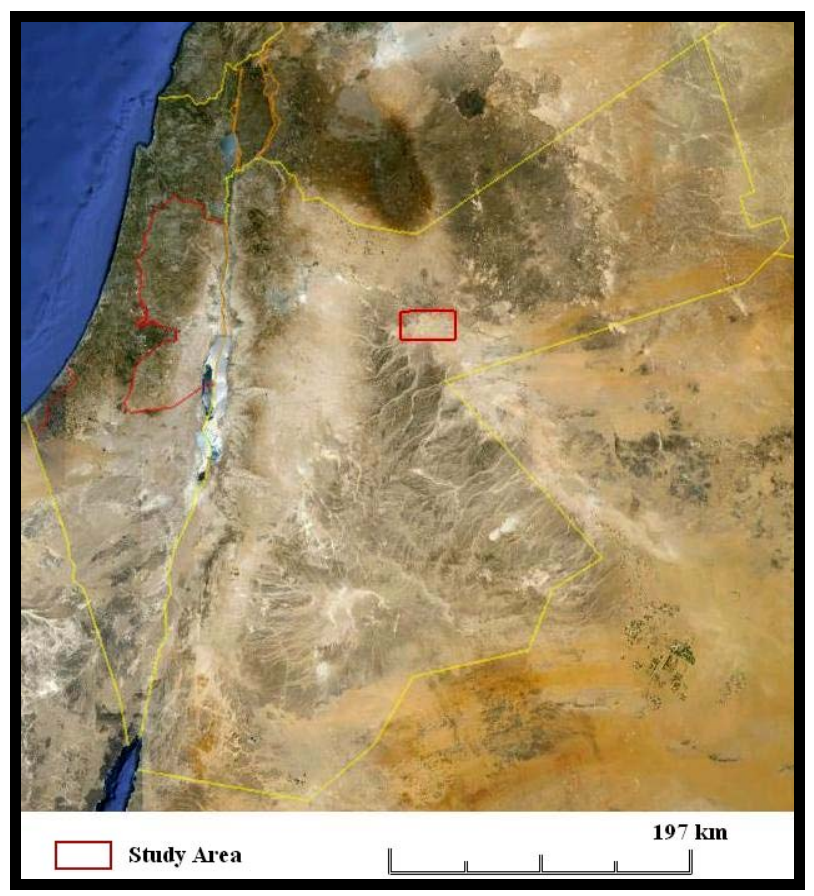

Figure 1. The study area location within Jordan (Google Earth $\left.^{\circledR}\right)$.

Table 1. Groundwater natural recharge selection criteria (After [3,8,18]).

\begin{tabular}{ccc}
\hline Criterion & Suitable (1) & Not Suitable (0) \\
\hline Slope (\%) & $\leq 2$ & $>2$ \\
Drainage Density $\left(\mathrm{km} / \mathrm{km}^{2}\right)$ & $\leq 1$ & $>1$ \\
Lineament Density $\left(\mathrm{km} / \mathrm{km}^{2}\right)$ & $\geq 1$ & $<1$ \\
\hline
\end{tabular}

\subsection{Data Collection}

In order to find suitable sites for the groundwater recharge projects, the following secondary data were gathered as shown in Table 2. Figures 2, $\mathbf{3}$ and $\mathbf{4}$ shows the major GIS layers used in this research.

Table 2. Used GIS layers.

\begin{tabular}{ll}
\hline GIS Layer & Scale and Source \\
\hline $\begin{array}{l}\text { Digital Elevation Model } \\
\text { (DEM) (Figure 2) }\end{array}$ & $\begin{array}{l}\text { 30 m SRTM (Shuttle Radar Topography } \\
\text { Mission) of United States Geological }\end{array}$ \\
$\begin{array}{ll}\text { Survey (USGS) } \\
\text { Drainage (Figure 3) }\end{array}$ & $\begin{array}{l}\text { Extracted from the SRTM USGS DEM } \\
\text { Lineament (Figure 4) } \\
\text { and Technology (1998) }\end{array}$ \\
\hline
\end{tabular}

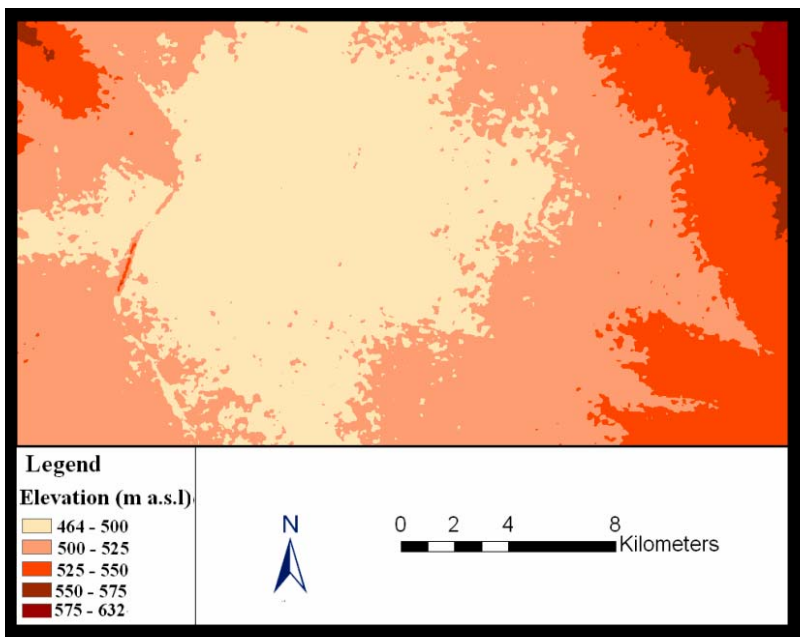

Figure 2. DEM used in this research.

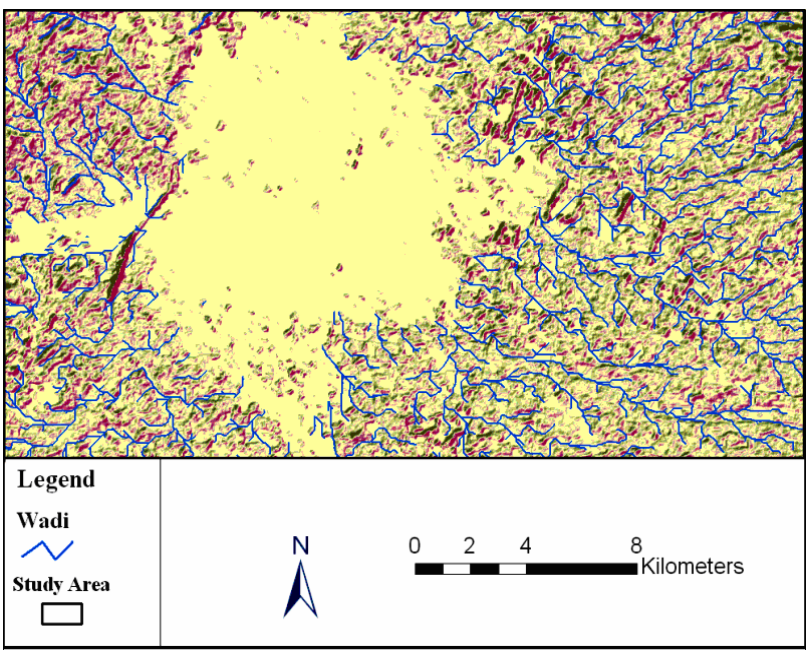

Figure 3. Drainage layer used in this research (Extracted from the USGS DEM). 


\section{Data Analysis and Results}

Figure 5 illustrates the adopted data analysis methodology in this paper. This figure shows that each GIS layer has been operated on separately in order to fulfill the conditions stated in Table 1. A DEM was created using 30 m USGS SRTM data, then, a slope raster map was created. The slope was classified into $<=2 \%$ (suitable) and $>2 \%$ (unsuitable) (Figure 6).

Using the USGS SRTM Data, the drainage map (Wadi) was extracted (Figure 3). This map was subjected to density calculation in ArcGIS and then classified based on Table 1 as shown in Figure 7. The lineament map was also subjected to density calculation, and then classified according to Table $\mathbf{1}$ as shown in Figure 8, where the suitable areas in all maps (Figures 6, 7 and 8) were given1, while the unsuitable ones were given 0 .

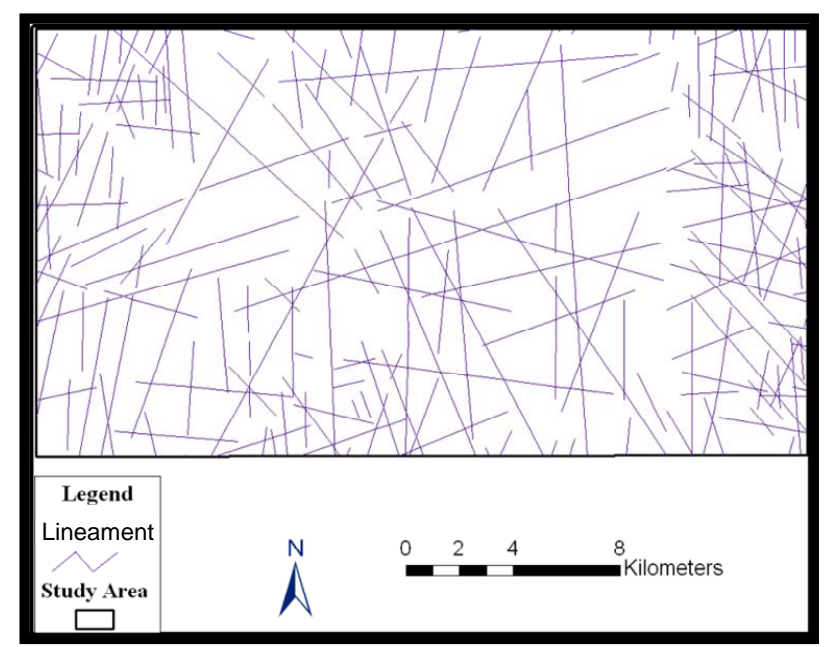

Figure 4. Lineament layer used in this research.

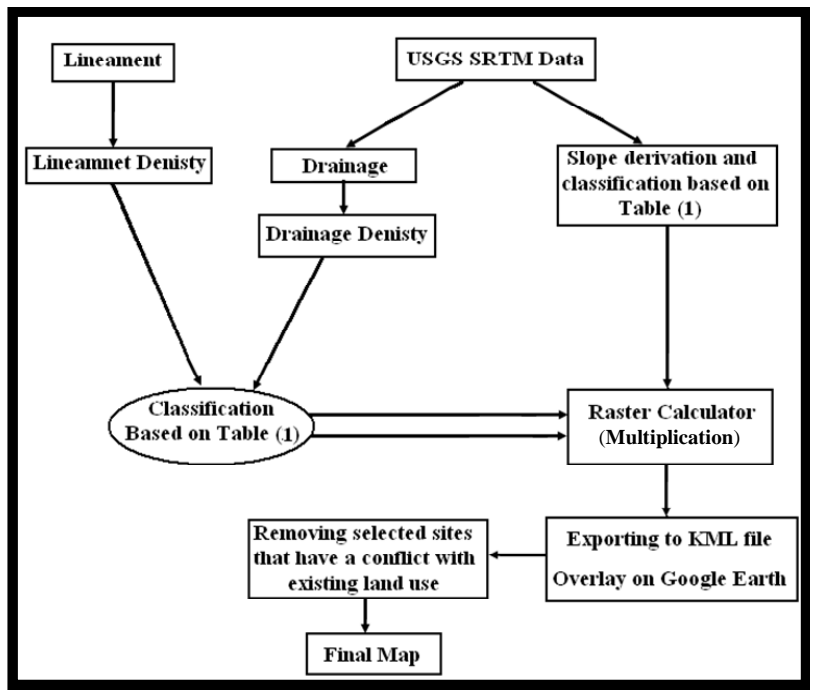

Figure 5. The methodology of data analysis within GIS environment.

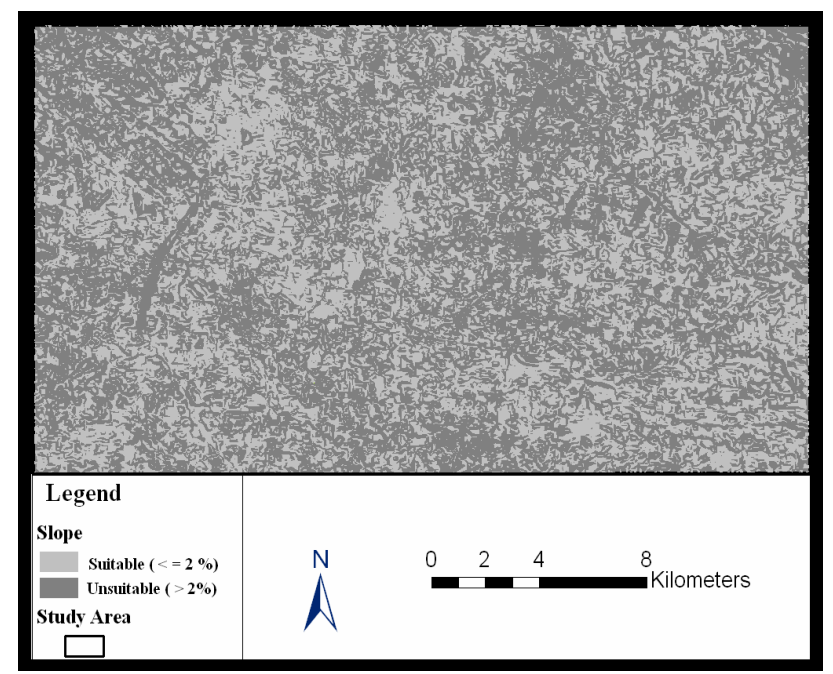

Figure 6. Slope (\%) classification.

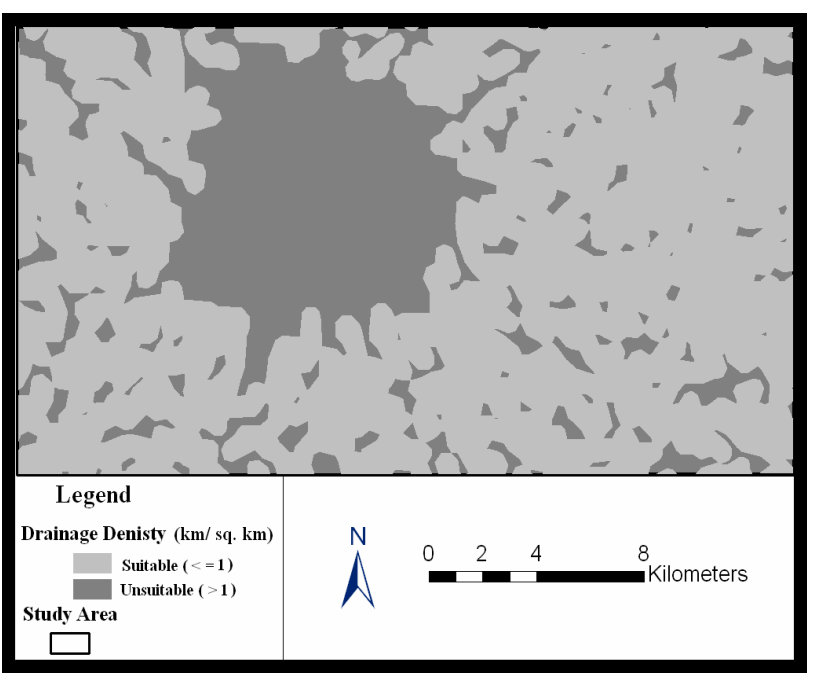

Figure 7. The drainage density (km/ sq. km).

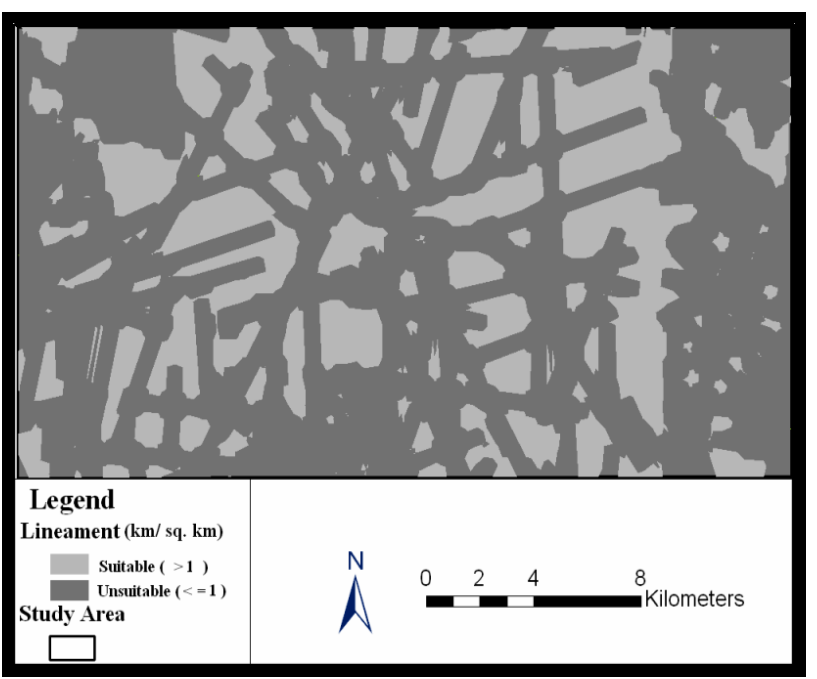

Figure 8. The lineament density (km/ sq. km). 
Using the raster calculator in ArcGIS, maps shown in Figures 6, 7 and 8 were multiplied. Then, the resulted map was exported to KML format and overlaid on Google Earth ${ }^{\circledR}$ (Figure 9). This step was essential in order to overcome any overlap between the selected sites and existing land uses in the area. Finally, all sites that have area of less than 5 ha were removed from the final map. The final map is shown in (Figure10). The areas of the selected sites (35 sites) vary between 5.2 ha and 273.5 ha. The total area that has the potential for groundwater recharge is 1659.5 ha which represents approximately $3.55 \%$ of the study area.

\section{Conclusions and Recommendations}

Based on the finding of this research, it is concluded that:

1) Selecting the optimum sites for groundwater recharge is an important issue for Jordan due to the water shortage in the country and to assist in reversing the negative impacts of overexploiting of the limited groundwater resources. Implementing groundwater recharge projects in Jordan will help in achieving a balance between total pumping and recharge;

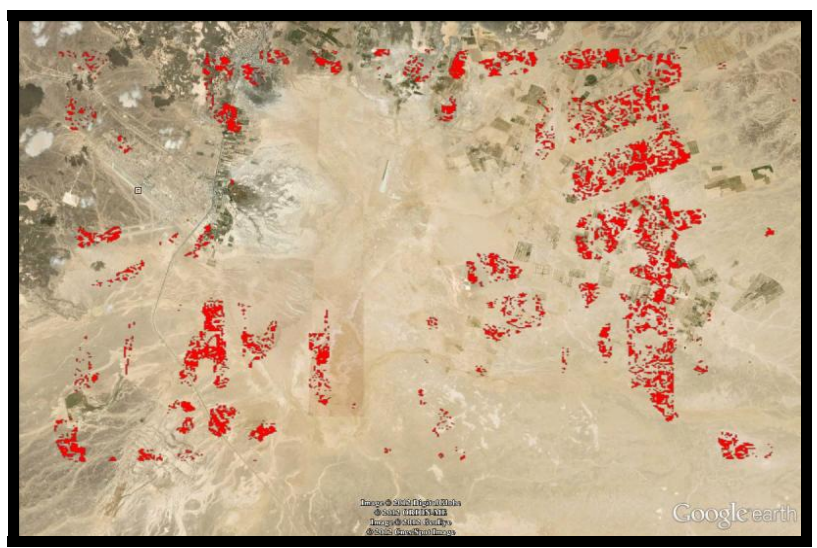

Figure 9. The selected sites overlaid on Google Earth ${ }^{\circledR}$ image.

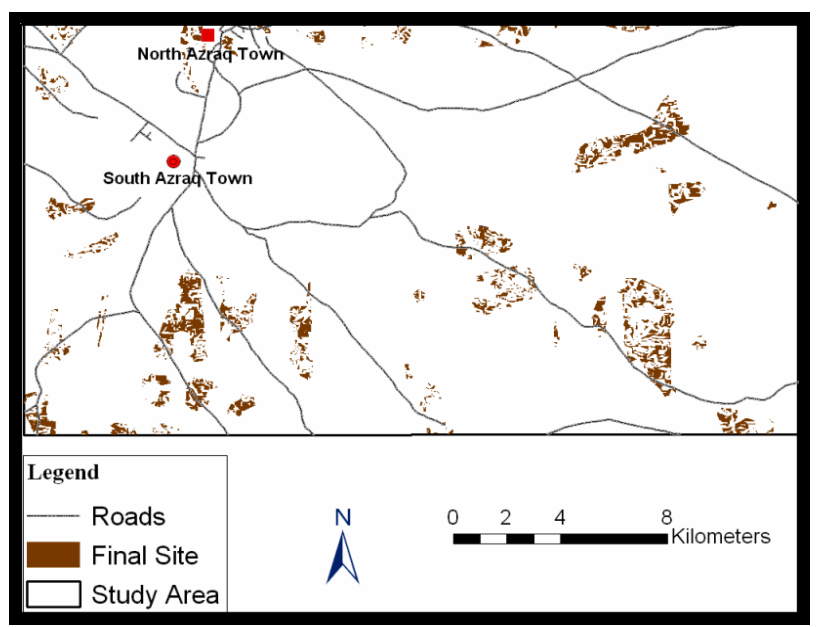

Figure 10. The final suitability map.
2) GIS facilitates the analysis of different parameters related to the selection of groundwater recharge sites;

3) GIS is an effective tool for locating the optimum sites for groundwater recharge based on the available spatial data.

It is recommended to refine the outcomes of this research by introducing more criteria. Additional criteria may include but not limited to:

a) Rainfall,

b) Static Water Level,

c) Vadose Zone,

d) Land use/Land cover,

e) Aquifer Hydraulic conductivity,

f) Soil (Texture and hydraulic conductivity).

Also, it is recommended to conduct an on-site investigation for the selected sites including:

a) Geophysical investigation and

b) Soil analysis.

\section{REFERENCES}

[1] E. Salameh and H. Bannayan, "Water Resources of Jordan, Present Status and Future Potentials,” Friedrich Ebert Stiftung, Amman, 1993, 183 p.

[2] M. E. Reid and S. J. Dreiss, "Modeling the Effect of Unsaturated, Stratified Sediments on Groundwater Recharge from Intermittent Streams,” Journal of Hydrology, Vol. 114, No. 1-2, 1990, pp. 149-174. doi:10.1016/0022-1694(90)90079-D

[3] A. M. S. Juaidi, "GIS-Based Modeling of Groundwater Recharge for the West Bank,” Unpublished M.Sc. Thesis, An-Najah National University, Nablus, 2008.

[4] J. Ghayoumian, B. Ghermezcheshme, S. Feiznia and A. A. Noroozi, "Integrating GIS and DSS for Identification of Suitable Areas for Artificial Recharge, Case Study Meimeh Basin, Isfahan, Iran,” Environmental Geology, Vol. 47, No. 4, 2005, pp. 493-500. doi:10.1007/s00254-004-1169-y

[5] I. Chenini, A. B. Mammou and M. E. May, "Groundwater Recharge Zone Mapping Using GIS-Based Multi-Criteria Analysis: A Case Study in Central Tunisia (Maknassy Basin),” Water Resources Management, Vol. 24, No. 5, 2010, pp. 921-939. doi:10.1007/s11269-009-9479-1

[6] I. Chenini and A. B. Mammou, "Groundwater Recharge Study in Arid Region: An Approach Using GIS Techniques and Numerical Modeling," Computers \& Geosciences, Vol. 36, No. 6, 2010, pp. 801-817. doi:10.1016/j.cageo.2009.06.014

[7] A. P. Sargaonkar, B. Rathi and A. Baile, "Identifying Potential Sites for Artificial Groundwater Recharge in SubWatershed of River Kanhan, India,” Environmental Earth Sciences, Vol. 62, No. 5, 2010, pp. 1099-1108. doi:10.1007/s12665-010-0598-z

[8] M. S. Shirahatti, M. V. Ranghswami, R. Sivasamy, S. S. Bosu, M. V. Manjunath and M. B. Guled, “Application of Remote Sensing and GIS Techniques for Groundwater Recharge Site Selection in Hard Rock Areas-A Case Study 
from South India,” 2010. http://crida.ernet.in/TOT-Winter\%20School/MSS\%20et al.pdf

[9] C. F. Vorhauer and J. M. Hamlett, "GIS: A Tool for Siting Small Farm Ponds," Journal of Soil and Water Conservation, Vol. 51, No. 5, 1996, pp. 434-438.

[10] J. R. Eastman, “Idrisi for Windows, User's Guide, Version 2.0, Clark Labs for Cartographic Technology and Geographic Analysis,” Clark University, Worcester, 1997.

[11] S. Baban and K. Wan-Yusof, "Modelling Optimum Sites for Locating Reservoirs in Tropical Environments," Water Resources Management, Vol. 17, No. 1, 2003, pp. 117. doi:10.1023/A:1023066705226

[12] J. Malczewski, "GIS-Based Land-Use Suitability Analysis: A Critical Overview,” Progress in Planning, Vol. 62, No. 1, 2004, pp. 3-65. doi:10.1016/j.progress.2003.09.002

[13] G. Shatnawi, "Determine the Best Sites forWater Harvesting Projects (Dams \& Hafirs) in Northeastern Badia Using GIS Applications,” Unpublished M.Sc. Thesis, Al Al-Bayt University, Mafraq, 2006.

[14] L. Ayalew and H. Yamagishi, "The Application of GISBased Logistic Regression for Landslide Susceptibility Mapping in the Kakuda-Yahiko Mountains, Central Japan,” Geomorphology, Vol. 65, No. 1-2, 2005, pp. 15- 31. doi:10.1016/j.geomorph.2004.06.010

[15] A. Yalcin, “GIS-Based Landslide Susceptibility Mapping Using Analytical Hierarchy Process and Bivariate Statis- tics in Ardesen (Turkey): Comparisons of Results and Confirmations,” Catena, Vol. 72, No. 1, 2008, pp. 1-12. doi:10.1016/j.catena.2007.01.003

[16] R. Al-Adamat, A. Diabat and G. Shatnawi, "Combining GIS with Multicriteria Decision Making for Siting Water Harvesting Ponds in Northern Jordan," Journal of Arid Environments, Vol. 74, No. 11, pp. 1471-1477. doi:10.1016/j.jaridenv.2010.07.001

[17] V. Madrucci, F. Taioli and C. C. De Araújo, “Groundwater Favorability Map Using GIS Multicriteria Data Analysis on Crystalline Terrain, Saeo Paulo State, Brazil,” Journal of Hydrology, Vol. 357, No. 3-4, 2008, pp. 153-173. doi:10.1016/j.jhydrol.2008.03.026

[18] R. Al-Adamat, "GIS as a Decision Support System for Siting Water Harvesting Ponds in Jordan,” Journal of Environmental Assessment Policy and Management, Vol. 10, No. 2, 2008, pp. 189-206. doi:10.1142/S1464333208003020

[19] N.-B. Chang, G. Parvathinathan and J. B. Breeden, “Combining GIS with Fuzzy Multicriteria for Landfill Siting in a Fast-Growing Urban Region,” Journal of Environmental Management, Vol. 87, No. 1, 2008, pp. 139-153. doi:10.1016/j.jenvman.2007.01.011

[20] P. C. Longdill, T. R. Healy and K. P. Black, “An Integrated GIS Approach for Sustainable Aquaculture Management Area Site Selection,” Ocean \& Coastal Management, Vol. 51, No. 8-9, 2008, pp. 612-624. doi:10.1016/j.ocecoaman.2008.06.010 